\title{
Laparoscopic repair of incisional hernia: Outcomes of 100 consecutive cases comprising 25 wall defects larger than $15 \mathrm{~cm}$
}

Giovanni Carlo Ferrari • Angelo Miranda •

Stefano Di Lernia - Fabio Sansonna · Carmelo Magistro •

Dario Maggioni - Ildo Scandroglio - Andrea Costanzi ·

Maurizio Franzetti $\cdot$ Raffaele Pugliese

Published online: 6 March 2008

(C) Springer Science+Business Media, LLC 2008

\section{Erratum to: Surg Endosc}

\section{DOI 10.1007/s00464-007-9707-9}

(1) On 1st page of article, right-hand column, 4th paragraph, 7th line, change " $(>20 \mathrm{~cm})$ " to " $(>15 \mathrm{~cm})$ ".

(2) On 2nd page, Table 1 title, change "according to Chevrel [9]" to "modified from Chevrel $[8,9]$ ".
(3) On 6th page, left-hand column, 7th line from end of Discussion, change "since Chevrel defined as "giant" only hernias larger than $20 \mathrm{~cm}$ [29]" to "since Bernard considered as "giant" hernias with surface of $182 \mathrm{~cm}^{2}$ [19]."

The online version of the original article can be found under doi: 10.1007/s00464-007-9707-9.

G. C. Ferrari - A. Miranda - S. D. Lernia · F. Sansonna ( $₫)$.

C. Magistro - D. Maggioni - I. Scandroglio - A. Costanzi ·

M. Franzetti · R. Pugliese

Surgery and Videolaparoscopy Department, Niguarda Hospital,

Milan, Piazza Ospedale Maggiore 3, 20162 Milano, Italy

e-mail: fabios55@libero.it 